Karol B. JANOWSKI

Warszawa

www.astercity.net/ janowski

\title{
Polska wobec kulturowych dylematów i wyzwań „europejskości”
}

\section{Kulturowe aspekty „europejskości” Polaków}

W Środkowej i Wschodniej. Zapewne są one w części przejawem polonocentryzmu. Jednakże nie do pominięcia są przypadki sięgania po wzorce zmiany politycznej w Polsce, jak i wiązania z nią oczekiwań i nadziei na stworzenie wspólnego frontu, przybliżającego skuteczne porzucenie imperialnych ograniczeń $^{1}$. Jednakże istotą przeobrażeń w regionie, było emocjonalne odrzucenie dotychczasowego systemu, wyrażające się w „ucieczce ze Wschodu”.

Dotąd rewolucje obalając stare porządki, wprowadzając nowe, sięgały po ideologiczne uzasadnienie oraz opierały się na nowej doktrynie. Natomiast jej polska odmiana nie oferowała niczego, czego dotąd nie doświadczono. Miała znamiona restauracji „kroczącej”, czerpała z przeszłości, równocześnie była zorientowana na przyszłość. Odejście od porządku „realnosocjalistycznego" nie przyjęło formy jednorazowego aktu; nie stało się nim także przejście do ładu nowego. W sensie teoretycznym pozostało abstraktem odzwierciedlającym w najogólniejszych zarysach idealny obraz społeczeństwa rozwiniętego rynku i demokracji. W aspekcie cywilizacyjnym droga, na jaką wkroczyła Polska miała jej zapewnić powrót do umownie określanej Europy (włączając Stany Zjednoczone Ameryki Północnej). To podejście zdaje się być najbliższe modernizacji, u której podstaw legła wiara w uniwersalny walor euro-amerykańskiego wzorca cywilizacyjnego. W „,powrocie do Europy” mieściły się przede wszystkim oczekiwania cywilizacyjne. Przekładały się one na wolę opu-

1 Por. A. Burakowski, A. Gubrynowicz, P. Ukielski, 1989 - Jesień Narodów, Warszawa 2009; Vide: K. B. Janowski, Węry. Rok 1989 (Próba analizy teoriopolitycznej), „Przegląd Politologiczny” 1999, nr 1-2. 
szczenia obszaru regresu i ubóstwa. To, co członkowie społeczeństw tego regionu pojmowali jako „społeczeństwo nowoczesne” znaczyło zatem „normalność”, czyli stereotypowe wyobrażenie o społeczeństwie, państwie prawa i dostatku.

Obserwacja różnych aspektów życia społecznego w Polsce skłania do sformułowania wniosku, iż przejście od reżimu autorytarnego do demokratycznego jest procesem wykazującym niemożliwy do zakwestionowania postęp. Jego przebieg, pozbawiony gwałtownych starć i konfliktów, był możliwy m.in. wskutek nasycenia porządku realnosocjalistycznego w jego schyłkowej fazie elementami mieszczącymi się, stanowiącymi zapowiedź bądź niesprzecznymi z ładem pluralistycznym. W tym zawiera się opozycja, ale jednocześnie ciągłość, wprawdzie fragmentaryczna, jednakże niemożliwa do pominięcia, jeśli oceniać efekty zmiany politycznej. Mając na względzie najogólniejsze standardy polityczne, Polska nie odbiega od form praktykowanych przez państwa członkowskie UE ${ }^{2}$. Jej potencjał gospodarczy, społeczny oraz warunki geopolityczne czynią z niej ponadto niemożliwy do pominięcia element europejskiego krajobrazu.

Pojawia się wszakże pytanie, czy owe najogólniejsze konstatacje wystarczą, by uznać, że „europejskość” Polaków jest faktem? Ważnym elementem zmiany jest kultura polityczna. O ile przyjąć klasyczne ujęcie Gabriela A. Almonda, Sidneya C. Verby i Bighmana G. Powella, to istotnym punktem odniesienia zdaje się pozostawać ideał „uczestnictwa” w polityce. Jego urzeczywistnianie wiąże się z powszechnością i demokracją taka forma wymaga „spójnej z nią kultury politycznej”.

Idąc tym tropem, interesująco poznawczo rysuje się wykorzystanie w analizie kultury politycznej Polaków amerykańskiego konceptu oraz zastosowanie choćby części instrumentarium badawczego ${ }^{3}$. Analiza okresu

2 Por. konstatację J. Jaskierni, która wprawdzie odnosi się do Rady Europy - stanowiącej krok „na drodze do urzeczywistnienia idei integracji europejskiej” - jednakże odzwierciedla istotę „wspólnotowych” standardów. Tworzą ją: „pluralistyczna demokracja, system ochrony praw człowieka, pochodzący z wolnych wyborów parlament". J. Jaskiernia, Zgromadzenie Parlamentarne Rady Europy, Warszawa 2000, s. $29-30$.

3 Autor nie poprzestał na opisie amerykańskiego konceptu kultury politycznej, lecz podjął próbę jego zastosowania do analizy casusu polskiego, przedstawiając efekty przemyśleń w: Kultura polityczna. Podstawowe pojęcia oraz ich znaczenie i użyteczność, „Przegląd Politologiczny” 2002, nr 1; także w podręczniku pt. Wprowadzenie do nauki o państwie i polityce, red. B. Szmulik, M. Żmigrodzki, Lublin 2002. Ponadto od połowy lat dziewięćdziesiątych w czasopismach naukowych oraz pracach zbiorowych 
po przełomie 1989 r., skłania do stwierdzenia, iż kulturę polityczną Polaków charakteryzuje niejednolitość. „Uczestnictwo” współegzystuje z ,podporządkowaniem”, czemu towarzyszy „zaściankowość”. Zachowania polityczne współczesnych Polaków w znacznej mierze określa względnie niski stan wiedzy na temat systemu politycznego, emocjonalny doń stosunek, niezdolność wskazania obiektów reprezentacji politycznej (obiekty „inicjujące”), brak przekonania co do roli jednostki (,szeregowego obywatela"). Polakom nastręcza trudności zlokalizowanie realnej władzy. W dużym stopniu jest to skutek niezdolności jej skonkretyzowania (zdefiniowania) oraz opisowego rozpoznania. W świadomości społecznej jest ona rozproszona. Jednakże to rozproszenie nie ma charakteru prawno-konstytucyjnego, lecz jest skutkiem braku rozeznania co do formalnego umocowania władzy i jej możliwości. Po wtóre, w odniesieniu do niej przeważa nastawienie wartościująco-emocjonalne, odzwierciedlające wzmożone napięcie afektywne.

Wprawdzie wypadnie zachować powściagliwość wobec wyników badań opinii publicznej, której źródłem jest niedostatek w społeczeństwie wiedzy nt. zjawisk i procesów politycznych, niestabilność nastrojów społecznych, wpływ „poprawności politycznej” na ich dynamikę ${ }^{4}$, do czego przyczyniają się także badania opinii publicznej. Niemniej jednak za punkt analizy oczekiwań i nadziei „szeregowego” obywatela można przyjąć wyniki badań zawarte w raporcie „Diagnoza społeczna 2003 r.” Sygnalizowały one wzrost niezadowolenia ze stanu spraw państwa oraz zjawisko wycofywania się obywateli w sferę prywatności, motywowane

publikował analizy nt. przeobrażeń i stanu kultury politycznej Polaków. J. Garlicki, A. Noga-Bogomilski w godnej odnotowania książce (Kultura polityczna w spoleczeństwie demokratycznym, Warszawa 2004) nie zauważają owych prób. Nie dostrzegają także efektów przemyśleń autorów z różnych ośrodków naukowych, podjętych podczas kolejnych konferencji nt. kultury politycznej organizowanych w UAM w Poznaniu od połowy lat 90-tych z inicjatywy Marcelego Kosmana. Zaskakuje fakt, że w dziele zbiorowym Teoretyczne i metodologiczne problemy badań nad kultura politycznq, wydanym przez oficynę uniwersytecką (red. Z. Blok, Poznań 2005), pomija się te dokonania, nie wykraczając poza konstatacje rekapitulujące znane dotąd i przywoływane rozważania i konstatacje nt. teorii i metodologii badań kultury politycznej. W tym kontekście nasuwa się wszakże ogólna uwaga tycząca w ogóle „czytelnictwa” wśród Polaków, a naukowców w szczególności.

${ }^{4}$ W tej kwestii nader interesujące rozważania Teresy Sasińskiej-Klas, Hipoteza „spirali milczenia” i jej zastosowanie w sferze publicznej, w: Opozycja w systemach demokratycznych i niedemokratycznych, red. K. Łabędź, M. Mikołajczyk, Kraków 2001. 
brakiem zaufania do polityki, do instytucji politycznych oraz reguł i mechanizmów alokacji władzy. Braku więzi z państwem nie rekompensuje aktywność na rzecz społeczności lokalnych, na której dobro działało 13 proc. badanych; 12 proc. deklarowało przynależność do związków, stowarzyszeń, partii czy komitetów ${ }^{5}$. Duża część społeczeństwa nie dostrzega struktur, które zdolne są skutecznie reprezentować jej interesy, co powoduje apatię, alienację, wzmacniając poczucie bezradności. Ponadto nie zauważa zależności między kształtem sytemu politycznego i mechanizmami jego funkcjonowania a uczestnictwem i aktywnym wyrażaniem akceptacji bądź dezaprobaty, co przekłada się na małą aktywność polityczną (liczna „milcząca większość”).

Udziałem dużej części społeczeństwa jest labilność sympatii politycznych; falowanie nastrojów społecznych - od euforii do apatii. Rzadko wiąże się to z racjonalnymi przesłankami. Przeciwnie - nader często jest efektem zastosowania instrumentów marketingu na nieustabilizowanym rynku politycznym. Duża część społeczeństwa polskiego staje się więc wdzięcznym adresatem haseł demagogicznych, populistycznych, wręcz obiektem manipulacji. To ona - postrzegając w sposób mało wyrafinowany otaczającą rzeczywistość - gotowa jest ulec prymitywnemu językowi, zbudowanemu na syntetycznych, emocjonalnych komunikatach.

Wyrazem żywotności kultury „zaściankowej” są po pierwsze dążenia do ideologizacji i polityzacji różnych wymiarów egzystencji społeczeństwa, czy wpływanie na obiekty polityczne przez wspólnoty zintegrowane więzami lojalności grupowej (związki zawodowe). Po wtóre, brak wobec nich sprzeciwu, owocującego zauważalnymi efektami w wymiarze społecznym. Osobliwą rolę w kształtowaniu kultury politycznej odgrywa kościół katolicki ${ }^{6}$. Jako grupa interesu, uzyskał on pozycję uprzywilejo-

5 Żyjemy obok państwa. Sytuacja Polaków wedlug „,Diagnozy społecznej 2003 r.”, „Rzeczpospolita” z 16 października 2003. Por. Diagnoza społeczna 2009. Warunki i jakość zycia Polaków. Raport, red. J. Czapiński, T. Panek, Wyższa Szkoła Finansów i Zarządzania, Warszawa, http://www.diagnoza.com/pliki/raporty/Diagnoza_raport_2009.pdf, październik 2009.

${ }^{\overline{6}}$ O związkach kultury politycznej z cywilizacją łacińską oraz jej kościelnych źródłach pisze Jacek Bartyzel: „Jeżeli przeto przywiązujemy tak wielką wagę do wpływu cywilizacji na kulturę polityczna patriotyzmu, to nie mamy na myśli cywilizacji sensu largo, lecz konkretną cywilizację, która określa kształt i granice Europy, a więc także i naszej ojczyzny: cywilizację tacińska [...] o jej wartości przesądza fakt, że jest ona spadkobierczynią najznakomitszych cywilizacji antycznych [...] że jej istotą jest prymat (lecz nie negacja!) ducha nad materia, moralności nad prawem oraz 
waną, nieporównywalną do miejsca w społeczeństwach europejskich. W rezultacie, wpływa (bezpośrednio i pośrednio) na różnorodne sfery i instytucje życia publicznego, w tym prawo (np. wyjątki od przepisów $\mathrm{UE}^{7}$ ). Jego postawa i formy ekspresji, dyrektywy oraz podejmowane działania stanowią istotny punkt odniesienia dla postaw i zachowań polityków, urzędników, korpusu oficerskiego, sędziów (także Trybunału Konstytucyjnego), prokuratorów, policjantów, lekarzy i prawników [klauzula sumienia], nauczycieli, dziennikarzy...

Skuteczność kościoła w zaspokajaniu swych potrzeb stanowi swoisty wzorzec. Zawiera się on w zdecydowanym definiowaniu celów oraz konsekwentnym dążeniu do ich realizacji poprzez zastosowanie różnych środków i instrumentów wywierania wpływu i nacisku oraz gry i walki politycznej (w tym manipulacja, instrumentalizacja, fałsz, kamuflaż etc.). Niejednokrotnie cele, do osiągnięcia których kościół dąży, są przesłaniane szczytnymi intencjami (np. określenie „dzieło boże” może znaczyć przedsięwzięcie biznesowe), bądź formułowane ezopowym językiem (intencje deklarowane i rzeczywiste). Szczególne miejsce zajmują tu niejawne, zakulisowe negocjacje. Ich rzeczywiste cele i sens skrywają deklaracje i przesłania sytuowane na poziomie wartości religijnych, etyki, moralności, misji etc.

Siłą prawa, obyczaju i zwyczaju uzyskał kościół instytucjonalny uprzywilejowaną pozycję, która zaspakaja jego publiczno-prawne aspiracje oraz materialne potrzeby. Są one pokrywane nierzadko wbrew prawu, bądź w efekcie jego naginania $z$ budżetu państwa (podatki ogółu obywateli) ${ }^{8}$.

osoby nad kolektywem, wszystko to zaś wypływa z «wychowania» tej cywilizacji przez Kościół katolicki, który jest depozytariuszem Prawdy absolutnej [...] cywilizacja łacińska (Christianitas) mogła wywierać, i faktycznie wywierała, zbawienny wpływ na narodowość i patriotyzm dlatego, że była budowana na fundamencie Dobra i Prawdy, pochodzących od Boga, że stanowiła próbę wcielenia nauki Chrystusowej w doczesności, nie tylko jednostkową, lecz i zbiorową: że przeświecał jej ideał Społecznego Panowania Chrystusa Króla”. J. Bartyzel, Patriotyzm w kulturze politycznej, „Arcana” 2007, nr 1, s. 142.

${ }^{7}$ Względy światopoglądowe sprawily, że Polska nie zaakceptowała w całości - obok Wielkiej Brytanii (przesłanki społeczne, socjalne) - Karty Praw Podstawowych Unii Europejskiej.

${ }^{8}$ W rezultacie działań niekonstytucyjnej Komisji Majątkowej, wykraczającej poza regulacje prawne z 1989 r., kościół nie stroniąc od działań na granicy prawa, ale niejednokrotnie je łamiąc, przejmuje (określając to „odzyskiwaniem” dóbr utraconych w okresie „komunizmu”) ziemię, nieruchomości etc. Pozostaje podmiotem uprzywilejowanym - wobec braku ustawy reprywatyzacyjnej - w stosunku do innych. „To jest 
Za przyzwoleniem i z inicjatywy państwa nastąpiło przemieszanie sacrum i profanum w życiu publicznym. Ów stan został osiągnięty nie tylko w efekcie zasług kościoła (często odbiegających od rzeczywistych; w ancien régime był przeciwnikiem, kooperantem oraz jego beneficjentem ${ }^{9}$ ) bądź własnych starań, lecz przede wszystkim wskutek przychylności polityków. Przyczynili się oni po 1989 r. do budowania i ugruntowywania jego pozycji niezależnie od orientacji ideowo-politycznej. Upatrywali w nim środek służący efektywniejszemu osiaganiu zamierzonych celów. Sam kościół nie bronił się przed instrumentalizowaniem. Troszczył się, by nie utracić wpływu na podmioty czerpiące z jego doktryny i pozycji, przyzwolenia i zachęty.

Wzory - nie wyłączając symboli - lojalności grupowej, ufundowanej na przesłankach religijnych, są demonstrowane oraz skutecznie przenoszone na grunt życia politycznego, co skłania do wydobycia żywotności „zaściankowości” („parafianizmu”). Jej przejawem jest godzenie się znacznej części społeczeństwa ze stanem uprzywilejowania kościoła. Nie wywołuje on sprzeciwu i pojmowany jest jako norma. Kościołowi okazywany jest respekt i zaufanie. Traktowany jest jako ważny podmiot życia publicznego, bywa rozstrzygający o egzystencji społeczeństwa i jednostek $^{10}$. Czy ten element kultury politycznej Polaków przystaje do standardów europejskich?

ich sprawa, żeby się o to upominać" - skwitował ówczesny współprzewodniczący Komisji Majątkowej, bp. Tadeusz Pieronek (Cukierek dla rzqdu, wywiad dla „Trybuny” z 15 maja 1998 r.). Kościół oczekuje ponadto ustawy reprywatyzacyjnej, dzięki której odzyska „dopiero” majątek. Wiele wskazuje, iż przejęty dotąd przez kościół majątek przewyższa wartość utraconego; nota bene brak wiarygodnych danych dokumentujących efekty procesu „odzyskiwania” utraconych w czasach PRL dóbr.

9 Szerzej K. B. Janowski, Miejsce kościoła katolickiego w życiu publicznym RP, „Przegląd Politologiczny” 2007, nr 1.

10 B. Łaciak dostrzega „dużą jednolitość, powszechność i trwałość tradycyjnych obyczajów związanych" ze świętami religijnymi, dochodzi wszakże do wniosku, iż „Wprawdzie mamy zdecydowanie wyższy odsetek osób uczestniczących w praktykach religijnych, ale w ostatnich latach coraz częściej wybieramy indywidualną formę religijności, a deklaracja wiary nie idzie w parze z uznawaniem religijnych dogmatów czy nauki Kościoła. Podobnie jak w krajach zachodnich zaczyna wzrastać zainteresowanie różnymi wspólnotami i ruchami religijnymi zarówno w obrębie Kościoła katolickiego, jak poza nim". Obyczajowość polska czasu transformacji czyli wojna postu z karnawatem, Warszawa 2005, s. 333 i 334. 


\section{Styl uprawiania polityki. Od integracji do konfliktu}

Traktując kulturę polityczną Polaków jako realność, poddającą się opisowi i analizie, godzi się wydobyć wpływ na jej stan postaw i zachowań grup pretendujących do miana elity politycznej ${ }^{11}$, u których - jak sugerował Max Weber - „dążenie do władzy jest nieuniknionym środkiem” pracy, zaś „,instynkt władzy” należy do ich „normalnych cech” ${ }^{12}$. Sposób bycia, ekspresji, wyrażania dążeń sam w sobie ilustruje poziom ich kultury politycznej. Zawiera ponadto - poprzez oferowane wzory - preferencje co do jej kształtu i treści oraz postaw i stylów uczestnictwa w polityce.

Pożądanym stanem systemu politycznego jest jego stabilność oraz funkcjonalność wobec społeczeństwa. Kryterium to może posłużyć za podstawę do wyodrębnienia dwóch modeli kultury politycznej, w ramach których ważności nabiera styl uprawiania polityki. Właściwością pierwszego - integracyjno-konsensualnego - jest integracja, kompromis. Drugiego - konflikt, który o ile „oswojony” służy zresztą integracji ${ }^{13}$. Jeśli jednak przeważa, niosąc dezintegrację i dysfunkcję, jest wyróżnikiem drugiego typu (modelu) kultury politycznej - konfliktowego.

Przybliżając sens tej typologii ${ }^{14}$, godzi się zwrócić uwagę na fakt, iż w sierpniu-wrześniu 1980 r., po raz pierwszy w historii Polski, eskalacja konfliktu społeczno-politycznego została zażegnana na drodze kompromisu. Jednakże niezdolność reżimu do zapanowania nad narastającym konfliktem politycznym za pomocą środków perswazyjno-politycznych, skłonił go do zastosowania instrumentu drastycznego, mieszczącego się

11 Autor stosuje formułę zbieżną z konstatacją: „Rzec można zasadnie, że osoby stanowiące elitę oligarchiczną, sprawującą władzę polityczną i ekonomiczną, są w zatrważającej tylko mniejszości osobami, które można zaliczyć do arystokracji umysłowej, arystokracji przodowników kultury, do arystokracji politycznej [...] sterników", zdolnych oferować masom pożądane wzorce. J. Goćkowski, A. Woźniak, Demokracja $i$ oligarchia $w$ Polsce czasu transformacji, w: Transformacje systemowe $w$ Polsce i krajach postkomunistycznych. Studia i rozprawy, t. 5, red. M. Chałubiński, Pułtusk 2006, s. 204.

12 M. Weber, Polityka jako zawód i powołanie, Kraków 1998, s. 97.

13 R. Dahrendorf, Nowoczesny konflikt społeczny, Warszawa 1993, s. 12.

14 Szerzej K. B. Janowski, Między integracja a konfliktem. W kręgu refleksji nad kultura polityczna Polaków, „Przegląd Politologiczny” 2000, nr 3-4. Wstępnie koncept ów został zarysowany w artykule Kultura polityczna społeczeństwa polskiego $w$ dobie transformacji, w: Post-zimnowojenna Europa. Ku jedności czy nowym podziałom? (Post-cold War Europe. Cooperation or New Division?), red. T. Łoś-Nowak, Wrocław 1995. 
w typie konfliktowej kultury politycznej - stanu wojennego. Zawieszał on „obywatelskość” w „solidarnościowym” (etos sierpnia-września 1980) tego pojęcia rozumieniu. Lata osiemdziesiąte zdominował konflikt. Jego stronami była opozycja na czele z „S”, nastawiona na rozprawienie się z reżimem, który usiłował wyeliminować ,antysocjalistyczne zagrożenie".

„Okrągły stół” - u progu wiosny 1989 r. - wolą dotychczasowych przeciwników politycznych, przyniósł dominację podejścia konsensualnego. Następowało przejście od konfliktu destruktywnego do fazy konstruktywnej (wybory parlamentarne) ${ }^{15}$. Zdawało się, że odchodzi w przeszłość model kultury politycznej, oferującej antagonistyczne podziały i ufundowanej na ideologicznych zasadach, zaś układ bipolarny ulega rozproszeniu, monopol ustępuje pluralizmowi, a polityka odzyskuje rzeczywistą treść. Przedstawiciele formacji uczestniczących w zapoczątkowaniu zmiany politycznej w 1989 r. - tej, której korzenie tkwiły w porządku autorytarnym, jak i tej, która demonstrowała wobec niego sprzeciw - podlegali przeobrażeniom, odzwierciedlającym zbliżenie bądź oddalanie się od modelu integracyjno-konsensualnego. Współpraca i współdziałanie rychło uległy zakwestionowaniu, zaś obszary konsensusu zawężeniu. O ile „Okragły stół” był miejscem skrzyżowania dwóch modeli kultury politycznej - w rzeczywistości osłabienia konfliktowości - to dalszy okres nie powstrzymał procesu przemieszczania się ich komponentów. Tak więc wiele elementów kultury integracyjno-konsensualnej zostało zaabsorbowanych przez przedstawicieli formacji wywodzącej się z porządku realnosocjalistycznego. Z powodzeniem wykorzystywali oni mechanizmy demokracji, stając nierzadko w jej obronie. Natomiast - paradoksalnie - po stronie „solidarnościowej” wystąpiło zjawisko ich odrzucenia, przy równoczesnym przejęciu cech pozostających w opozycji wobec etosu , $\mathrm{S}^{, 16}$.

Wypadnie tedy dostrzec przypadki odradzania się wzorców i stereotypów oraz stylu uprawiania polityki właściwych porządkowi „realnosocja-

15 Por. K. B. Janowski, Źródła i przebieg zmiany politycznej w Polsce (1980-1989), Toruń 2004. W. Morawski powiada: ,porozumienia Okrąłego Stołu były udanym wysiłkiem zmierzającym do przekształcenia „błędnego koła” w „koła korzyści” (Zmiana instytucjonalna, Warszawa 1998, s. 13).

16 A. W. Jabłoński konstatuje ,zjawisko załamania się etosu transformacyjnego opartego na etyce „Solidarności” i zwrot w kierunku »polityki jako gry«” (A. W. Jabłoński, Etos i gra: dwa nurty w polskiej kulturze politycznej, w: Studia polityczne, red. A. W. Jabłoński, K. A. Paszkiewicz, M. S. Wolański, Wrocław 1995, s. 181-188). 
listycznemu"17. Chętnie sięgnęli po nie ci, którzy go potępili. Poddają ideologizacji różne obszary państwa, czyniąc z własnej tożsamości znak określający relacje z pozostałymi formacjami politycznymi. W imię doraźnych celów politycznych odtwarzany jest podział bipolarny. Nieobca temu jest manipulacja, polegająca na lokowaniu cech godnych najwyższego uznania - patriotyzmu, determinacji w przeprowadzeniu reform, zrozumienia dla potrzeb społeczeństwa i zdolności artykułowania jego rzeczywistych interesów, kreacji i obrony polskiej racji stanu - jedynie po własnej stronie. W praktyce nastapił proces odwracania się od etycznych ideałów sierpniowego zrywu (1980 r.).

Znakiem, który wyjątkowo wyraziście określa tożsamość formacji politycznych powołujących się na „solidarnościowy” rodowód jest „,antykomunizm", którego ostrze jest skierowane przeciw obumarłej doktrynie i ludzi ją wyznających. Źródła stosunku do „komunizmu” są - można rzec - mało wyrafinowane. Za sprawą treści zmiany politycznej, komunizm został uznany za doktrynę ex defintione skupiającą wszelkie nieprawości i niegodziwości, lokowany na tej samej płaszczyźnie co faszyzm (vide art. 13 Konstytucji RP). Stosunek do „komunizmu” - pojmowanego w perspektywie aksjologiczno-emocjonalnej, nie zaś analityczno-opisowym - jest w istocie wyrazem projekcji fobii i niepokojów, jakie są udziałem prawicy. „Antykomunistyczny” radykalizm, połączony z konceptem porzucenia kompromisu z ludźmi ancien régime, oznaczał sprzeniewierzenie się zasadom demokracji parlamentarnej, pozostaje w opozycji do ideałów, o realizację których walczyła opozycja demokratyczna.

Istotnie, pozycja lewicy uległa zakwestionowaniu na niestabilnym rynku politycznym w 2005 r. Stało się tak na skutek własnej nieporadności, braku doktrynalnej wyrazistości, niepodlegającym wątpliwości nieprawidłowościom, które obciążyły kojarzony z nią rząd oraz popełnionych błędów. Godzi się wszakże stwierdzić, że zdarzenia ,aferalne” nie wykraczały poza te, które były, i nadal sa, udziałem konkurencji politycznej. „Dokonania” prawicy w tym zakresie były niejednokrotnie skrywane bądź pomniejszane. Natomiast czyny lewicy za sprawą ,politycznej poprawności” wyolbrzymiane, a bywa-kreowane (,afera węglowa”, w tle śmierć B. Blidy) ${ }^{18}$. W ten sposób

${ }_{17}$ Por. K. B. Janowski, Stereotypy w polityce polskiej, „Przegląd Politologiczny” 2009, $\mathrm{nr}$ 1; http://www.astercity.net/ janowski/STEREOTYPY\%20W\%20POLITYCE\%20POLSKIEJ.pdf.

18 Tzw. „afera Rywina” była „wirtualnym” refleksem przedsięwzięć lobbyingowych nakierowanych na zablokowanie inicjatywy legislacyjnej zmierzającej do 
dążenie do zniszczenia lewicy nabierało wznioślejszego charakteru ${ }^{19}$. W artykułowaniu wrogości wobec lewicy nie ma różnic między wiodącymi partiami prawicy - dotyczą one co najwyżej sposobu bądź zalecanych instrumentów unicestwienia czy zmarginalizowania epigonów „komuny”20. Treść stosunku do „komunizmu” zachowuje cechy niezmienności, pozostając znakiem rozpoznawczym ugrupowań politycznych mieniących się prawicą. Punktem odniesienia jest tu swoiste odczytywanie dokonań i doświadczeń powojennego okresu, stając się też treścią nastawienia podzielanego przez część inteligencji ${ }^{21}$.

uchwalenia ustawy regulującej rynek medialny w Polsce. Instrumenty medialno-marketingowe (,czarny” PR) przeciwników okazały się efektywnym narzędziem „rażenia”: wyeliminowanie inicjatywy legislacyjnej oraz klęska formacji politycznej, która ją autoryzowała. Media zjednoczyły się z opozycją polityczną, która uzyskała - w warunkach rzeczywistej i wykreowanej klęski układu rządzącego - przewagę nad przeciwnikiem, przekonując wyborców o konieczności dokonania zasadniczego „przełomu” w polityce polskiej. Jednakże klęska lewicy „likwidowała” też sens zjednoczenia PiS i PO, partii bliskich sobie ideowo i mentalnie; starły się one następnie w walce o władzę. Zjawisko jednoczenia się prawicy wobec rosnącej w siłę lewicy można było zaobserwować w 1997, 2001 i 2005 r., kiedy silna pozycja lewicy, stawała się spoiwem działań prawicy, mobilizującej swe moce do jej eliminowania. To wszystko każe poddać falsyfikacji stereotyp lewicy polskiej, forsowany przez konkurentów politycznych.

19 SLD „mniej wolno, bo po szkarlatynie, po ciężkiej chorobie, jaką była PRL obowiązuje kwarantanna [...] mniej wolno także jako opozycji" - oto uzasadnienie owego nastawienia (E. Milewicz, Pamięć niemowlęcia, „Gazeta Wyborcza” z 18 lutego 2000. Por. A. Urbańczyk, Wszyscy sq równi, ale... Niektórym mniej wolno, „Trybuna” z 16 lutego 2000).

${ }^{20}$ Godzi się wspomnieć o niezanikających konfliktach między lewicą i prawicą w krajach europejskich, których przedmiotem są symbole bądź przeszłe wydarzenia. Przykładem Francja, gdzie konflikty sięgające 1789 r. nadal uruchamiają walki polityczne, ,a sprawa jest $\mathrm{w}$ dalszym ciagu otwarta; każda $\mathrm{z}$ tych dat nadal dzieli lewice i prawicę, klerykałów i antyklerykałów, postępowców i reakcjonistów, w ich wszystkich historycznie zdeterminowanych konstelacjach" - powiada Herbert Luethy, The State of France, London 1955, Secker a. Warburg, s. 29.

${ }^{21}$ K. B. Janowski, Stereotypy..., op. cit. W tym kontekście na uwagę zasługuje konstatacja Lipseta, który wyraża pogląd, że „,W większości stabilnych demokracji istnieje immanentna skłonność do lewicy", wskazując na inklinacje intelektualistów amerykańskich - jako m.in. pewna forma dystansu wobec panowania „,pieniądza” - ku orientacjom lewicowym, stwierdzając: „Intelektualista ma niezaprzeczalne prawo do atakowania status quo. Może to robić powracając do tradycyjnych wartości lub podążając do przodu i starając się osiagnąć marzenia o równości. Przez takie działanie intelektualista pomaga w podtrzymaniu konfliktu, który stanowi istotę systemu demokratycznego". S. M. Lipset, Homo politicus. Spoleczne podstawy polityki, Warszawa 1995, s. 299 i 367. 
Najogólniej można stwierdzić, że w Polsce postawy i zachowania grup przywódczych charakteryzuje niestabilność, nieprzewidywalność, niezdolność do kreowania wzorców postaw i zachowań mieszczących się w standardach demokratycznej kultury politycznej ${ }^{22}$. Nader często jest demonstrowane lekceważenie dla państwa, konstytucyjnych uprawnień czy pozycji jego organów. W krajach o stabilnych prawach i mechanizmach regulujących funkcjonowanie społeczeństw w ich różnych wymiarach, punktem odniesienia czyni się zwykle ustawę zasadniczą. W Polsce nie jest ona postrzegana jako trwały element określający strukturę oraz najogólniejsze organizacyjne i proceduralne reguły aktywności obywatela i działania państwa. Nie jest traktowana jako punkt odniesienia w rozważaniach o stanie państwa, społeczeństwa oraz w dysputach politycznych; pozostaje to w wyraźnej opozycji do ,uczestnictwa"23.

22 Oto przywódca drugiego pod względem liczebności klubu parlamentarnego - PiS - by zmniejszyć szanse wyboru ew. przeciwników urzędującego prezydenta, sugeruje istnienie informacji o charakterze niejawnym („tajemnica państwowa”), które nie pozwalają skrywać wątpliwości. Przypomniał, że ,,prezydent miał zastrzeżenia przed powołaniem Sikorskiego na ministra spraw zagranicznych” w 2007 r., natomiast „Komorowskiego i tak kompromituje obrona WSI, które były prostą kontynuacją komunistycznych wojskowych specsłużb. Każdy Polak powinien się zastanowić, zanim będzie głosować na kogoś takiego”. Haki na Radka Sikorskiego, wywiad Jarosława Kaczyńskiego dla „Newsweeka.pl” z 12 lutego 2010, http://www.newsweek.pl/artykuly/sekcje/polska/haki-na-radka-sikorskiego,53588,1, 15.02.2010. Antoni Macierewicz, poseł PiS, stwierdził (audycja Polska pośród afer, komisji śledczych i sporów; kto na prezydenta, emitowana przez Radio Maryja, 13.02.2010), że Bronisława Komorowskiego obciążają związki z WSI, zaś Radosława Sikorskiego uległość wobec „środowisk agenturalnych”. Radio Maryja stawia na Lecha Kaczyńskiego, „Gazeta Wyborcza" z 16 lutego 2010. Nagrania w Radio Maryja: http://www.radiomaryja.pl/query.php? _s=Polska+po\%B6r\%F3d+afer\%2C+komisji+\%B6ledczych $+\mathrm{i}+$ spor $\% \mathrm{~F} 3 \mathrm{w} \% 3 \mathrm{~A}+\mathrm{kto}+$ na + Prezydenta $\% 3 \mathrm{~F}+\mathrm{cz} .+\mathrm{II} \& \_\mathrm{a}=1,16.02 .2010$. D. Tusk, prezes RM zwrócił się, 16.02.2010, do prezydenta RP, by ten ujawnił zarzuty wobec Sikorskiego (ministra spraw zagranicznych); „czas skończyć z polityką insynuacji” - oświadczył Tusk. Zardzewiaty hak na szefa MSZ, „Gazeta Wyborcza” z 17 lutego 2010.

23 Przeciwnie, zjawiskiem zyskującym na powszechności jest nie tylko instrumentalne traktowanie ustawy zasadniczej, ale próby jej doraźnego „przykrawania” do bieżącego przebiegu dramy politycznej. Oto PiS opublikował projekt zmian w konstytucji, które zmierzają do umocnienia urzędu prezydenta. Projekt nowej Konstytucji Rzeczypospolitej Polskiej, 15 stycznia 2010, http://www.pis.org.pl/dokumenty.php?s=partia\&iddoc $=149,15.01 .2010$. Natomiast PO (D. Tusk i G. Schetyna na spotkaniu w warszawskiej giełdzie papierów wartościowych, 12.02.2010) przedstawiła założenia do zmiany konstytucji, zmierzające w kierunku przeciwnym; http://www.platforma.org/pl/aktualnosci/newsy/art1932,proponujemy-zmiany-w-kon- 
Sami politycy swoją postawą i zachowaniem zachęcają do lekceważenia prawa. Zdają się sugerować, że instytucje ufundowane na prawie są niewystarczająco skuteczne dla urzeczywistniania społecznie ważnych (w ich mniemaniu) interesów. Nieposzanowanie ,godnych” obyczajów (w tym parlamentarnego ${ }^{24}$ ), kwestionowanie i podważanie prawa ${ }^{25}$, wręcz jego łamanie stało się wszak udziałem polityków. Ich działania oraz bezkarność zadaje cios społeczeństwu, państwu, jego instytucjom oraz prawu ${ }^{26}$. Ową konstatację odnosić wypadnie szczególnie do ekip „solidarnościowych". Przeważające znaczenie mają postawy i zachowania zwycięzców z 1989 r. oraz formacji politycznych, powołujących się na „,solidarnościowy" rodowód, które na polskiej scenie od tego momentu dominują.

Osobliwego dopełnienia doczekał się „syndrom władzy”, w tym sposób i zakres realizacji zasady „lex spolia”, kiedy konflikt, i „zarządzanie” nim, okazał się dominującym elementem gry politycznej. Oto niedawno rządząca ekipa, deklarująca przezwyciężenie i odrzucenie „,peerelowskich” mechanizmów, nie wahała się działać w sposób wskazujący na reanimowanie potępianych wzorców. Udatnie zawłaszczyła państwem w jego różnych wymiarach i obszarach, nie pomijając żadnej z wyróżnionych przez Monteskiusza władz. Celem stały się nie tylko strategiczne ogniwa władzy państwowej, a więc warunkujące realizację programu, lecz także o charakterze techniczno-administracyjnym. Hasło „TKM” („Teraz K...a MY „27)

stytucji.html, 14 lutego 2010; Tusk: Weto stabsze, posłów i senatorów mniej, „Gazeta Wyborcza" z 13-14 lutego 2010.

24 Por. K. B. Janowski, Obyczaj parlamentarny, w: Encyklopedia politologii, t. 2, red. W. Skrzydło, M. Chmaj, Kraków 2000.

25 Lech Kaczyński odmówił zastosowania się do orzeczenia SN, tj. przeproszenia powodów (L. Wałęsy i M. Wachowskiego), albowiem, wedle niego „oznaczałoby to, że Polska sięgnęła dna”. Prezydent Warszawy przegrat z Wałęsa $i$ Wachowskim. Kaczyński musi przeprosić, „Rzeczpospolita” z 17 września 2004. PiS wezwało urzędników państwowych do nieposłuszeństwa, sugerując im by „sprzeciwiali się antygospodarczym decyzjom rządu Belki”, obiecując ,daleko idące wsparcie wszystkim urzędnikom, którzy odważą się mówić”. Urzędnicy, odmawiajcie. PiS kontra Belka, „Gazeta Wyborcza” z 12 października 2004; PiS buntuje urzędników, „Trybuna” z 13 października 2004 .

26 A. Antoszewski zwraca uwagę na radykalizację części elektoratu i elit politycznych, która „objawia się w rosnącym dystansie [...] do elementów demokracji liberalnej" (Partie i systemy partyjne państw Unii Europejskiej na przełomie wieków, Toruń 2009, s. 20).

27 Określenia TKM (Teraz Kurwa My) użył publicznie Jarosław Kaczyński w 1997 r.; ,ja je jedynie spopularyzowałem. Usłyszałem je wcześniej od jednego 
- sformułowane przez człowieka „S” znającego zamiary ludzi jej „drugiego szeregu”, które odzwierciedlały osobliwy „głód” władzy oraz dążenie do usunięcia wszelkich „nie swoich” śladów z życia politycznego, zakreśliło koło, wracając do jego twórcy. Ideologizacja polityki oraz polityzacja różnych wymiarów egzystencji społeczeństwa wiodły - podobnie jak w ,peerelowskiej” rzeczywistości - do konfliktu.

W owych działaniach osobliwej rangi nabrały symbole. Nie służą one jednak pozytywnej, wspólnotowej identyfikacji - jako wyraz ,świeckiej kultury politycznej”28 - będącej fundamentem demokracji - lecz przede wszystkim różnicowaniu, antagonizowaniu, stając się socjotechnicznym narzędziem dystrybucji politycznej. Reanimuje się historyczne podziały polityczne, wykorzystując je do walki z ideologiczno-politycznym wrogiem, który - mitologizowany - urasta do rozmiarów najdramatyczniejszego wyzwania, przed którym staje naród polski. Odtwarzanie podziałów historycznych przypomina ideologiczno-polityczne oczyszczanie pola charakterystyczne dla skrajnej i ahistorycznej rewolucyjności. Utożsamiającej „obcość” z „wrogością”, przypisującej nieprawdę - wrogom, rozsiewającym zło - motywującej do walki na rzecz prawdy i dobra,

z kolegów” (M. Cieślik, Gięcie kobiet, „W Wrost” 2004, nr 7). Wyjaśniając powody, dla których nie startował w wyborach do Sejmu z listy AWS, chociaż uczestniczył w powoływaniu tej formacji, stwierdził wtedy, że zbyt wielką rolę odgrywała w niej nieformalna grupa, którą nazwał partią TKM. Kaczyński zarzucił jej „upartyjnienie” państwa - obsadzanie stanowisk w poszczególnych urzędach i instytucjach oraz spółkach Skarbu Państwa osobami związanymi z koalicją AWS, UW oraz „Solidarności", a także korzystanie z układów stworzonych przez poprzedników, przy równoczesnym zaniechaniu reform. Fraza „TKM” „przyjęta została nie tylko jako teza słuszna, ale i w swej dowcipnej dosadności absolutnie usprawiedliwiona”. M. Urbanek, Brzydkie wyrazy „Polityka” nr 33 (2154) z 15 sierpnia 1998. Tą wypowiedź zdawały się potwierdzać dane o korupcji i nepotyzmie w RP (Korupcja w Polsce: Przeglad obszarów priorytetowych i propozycje przeciwdziałania zjawisku. Raport Banku Światowego, Biuro w Warszawie z 11 października 1999 r.), jakkolwiek jego Porozumienie Centrum skorzystało wcześniej z zasobów „kapitalizmu państwowego", budując Telegraf, spółkę prominentnych działaczy partii (Jarosław i Lech Kaczyńscy, Maciej Zalewski, Andrzej Urbański, Krzysztof Czabański), powstałą w 1990 r., której m.in. kapitał - wskutek niewyjaśnionych dotąd machinacji finansowych i powiązań m.in. z bankiem BPH - w ciagu 10 miesięcy wzrósł 144 razy (Milczanowski, Telegraf umorzono niestusznie!, wywiad dla „Trybuny” z 25 marca 2009).

${ }_{28}$ Wg G. Almonda, świecka kultura polityczna” obejmuje m.in. wspólną symbolikę, rytuały narodowe i święta (Comparative Political Systems, „Journal of Politics” 1956, nr 18, s. 391-409), będące wyrazem wspólnej homogenicznej kultury Stanów Zjednoczonych (za: S. M. Lipset, Homo politicus, Warszawa 1995, s. 84-85). 
przeciwko kłamstwu i złu i narzucającej podziały dychotomiczne ${ }^{29}$. Występowanie owego mechanizmu charakteryzuje grupy podlegające mniej wyrafinowanym podnietom.

Tym samym przywracane są matryce postaw i zachowań wyczerpujących kanon „homo sovieticus”. Wprawdzie korzystanie z minionych wzorców nie jest czymś w dziejach ludzkości wyjątkowym. Współcześni nierzadko sięgają po przeszłe znaki, kody i symbole oraz ,przywdziewają" szaty dawnych aktorów, starając się urzeczywistniać własne zamysły $^{30}$. Ukazuje to znaczenie powtarzalności form, wzorców zachowań, a także treści systemów wartości. Odgradzanie się od PRL-owskiej przeszłości nie dotyczy jednak środków i sposobów uprawiania polityki. Ich bowiem zasób jest ograniczony; doprawdy niemożliwe jest kreowanie nowych, niepowtarzalnych form sterowania procesami politycznymi. Drama przebiega więc na demokratycznej scenie i na tle demokratycznych dekoracji, w których łacno sięga się po niedemokratyczne (anty-) instrumentarium. Ukazuje to stan swoistej schizofrenii, zawierającej się w jednoczesnym odrzuceniu i absorbowaniu „niechcianego” stylu uprawiania polityki ${ }^{31}$.

Pojawia się kwestia, czy zachowanie polskich przywódców, osobliwie „pierwszego” obywatela RP mieści się, czy odbiega od „europejskości”? Oto osoba, która mocą swego urzędu winna stać na straży nienaruszalności konstytucji RP, traktuje Rzeczpospolitą jako obszar władania, na którym przychodzi zmierzyć się z nieakceptowanymi ograniczeniami. Zwieńczeniem osobliwego ujmowania swej roli w państwie - któremu w sukurs

29 „Przeważnie jednak obcy jest zwalczany [...] Samoidentyfikacja jest bowiem podstawą poczucia istnienia zbiorowości jako odrębnej jednostki społecznej [...] Przez poczucie swej odrębności od innych ugrupowań najlepiej można przeżyć smak doniosłości swej egzystencji i jej specyficznych cech. Slogany i formuły ideologiczne pełnią często rolę analogiczną do owego swoistego zapachu wśród szczurów, po którym poznają swojego". A. Grzegorczyk, Filozofia czasu próby, Paryż 1979, s. 25-26.

30 Ten sposób adaptowania elementów przeszłości udatnie ukazał K. Marks, Osiemnasty brumaire'a Ludwika Bonaparte, Warszawa 1980, s. 11 i 13.

31 Odrzucanie potępianej przeszłości jest niekonsekwentne. Nie dotyczy np. wykształcenia, stopni naukowych, uzyskanych pod kierunkiem „socjalistycznej”, uwikłanej w „niegodny układ” profesury. Doprawdy trudno byłoby tego oczekiwać. Aliści kwestia pozostaje. Lech Kaczyński, rzecznik - wraz ze swym bratem - „rozprawienia się" z PRL, w latach 1971-1997 pracownik naukowy Uniwersytetu Gdańskiego; w 1980 r. uzyskał stopień dra n. prawnych, zaś 1 stycznia 1990 r. stopień dra habilitowanego nauk prawnych, http://nauka-polska.pl/dhtml/raporty/ludzieNauki? rtype $=$ opis\&objectId=30139\&lang=pl, 2 lutego 2010 . 
przychodzi małostkowość - jest interpretacja, jaką urzędujący prezydent poddaje regulacje konstytucyjne, określające uprawnienia głowy państwa. Niepomny konstytucyjnego umocowania prezydentury, zmierza do poszerzenia swych uprawnień. Nie jest to przypadek w historii Polski nowy (wcześniej Józef Piłsudski, w latach 90-tych Lech Wałęsa).

Pojawia się kwestia, w jakiej mierze źródłem owych roszczeń są niespełnione ambicje, egocentryzm, emocjonalny i konfliktowy, nierzadko irracjonalny, styl uprawiania polityki? Nie kryje on fobii, niepokojów, frustracji i podejrzliwości, wyolbrzymiając rolę spisku ${ }^{32}$. Ów sposób obecności w polityce zdaje się mieć znamiona paranoi politycznej ${ }^{33}$.

32 Urzędujący prezydent RP, przejawia obsesję na punkcie służb specjalnych i ich roli w minionym okresie. Przykładem - pogląd, iż Wałęsa ,jako prezydent oparł się na aparacie dawnych służb specjalnych - Kilka lat temu jeden z nieżyjących już dziś wybitnych polityków zwrócił mi uwagę, że walka o prezydenturę między Kwaśniewskim i Wałęsą w 1995 r. była w istocie rozgrywką między dwoma elementami tego samego aparatu: aparatem partyjnym i aparatem bezpieczeństwa. Pomyślałem wtedy, że dla mnie było to jasne od początku". Prezydent Kaczyński: Wałesa gorszy od Kwaśniewskiego, E-,,Wprost” z 11 marca 2007, http://www.wprost.pl/ar/?O=102766. Nieufność i obsesja co do zagrożeń płynących z otoczenia jest także właściwością brata prezydenta, co pozwala mówić o podobieństwach genetycznych. Jarosław Kaczyński począł korzystać z ochrony BOR (łącznie z pojazdem) od grudnia 2005 r., będąc szefem PiS, mimo że przywilej ten mu nie przysługiwał. Na mocy Art. 2. 1. 1) i 2) Ustawy z 16 marca 2001 r. o Biurze Ochrony Rządu (Dz. U. 2001, Nr 27 poz. 298) jego ochrona przysługuje prezydentowi RP, marszałkom Sejmu i Senatu, prezesowi i wiceprezesowi RM, ministrowi spraw wewnętrznych i spraw zagranicznych oraz innym osobom „ze względu na dobro państwa”. Ówczesny szef MSWiA przydzielił ochronę na prośbę prezydenta, ze względu na podobieństwo braci i wynikające stąd zagrożenia. „Chodzi mi o spokój prezydenta RP. Zasługuje na to, żeby nie musiał się o brata bliźniaka niepokoić. A bracia bliźniacy na ogół się o siebie niepokoją. Taka jest natura bliźniactwa" - mówił prezes PiS, zaznaczając, że ,jemu nikt nie groził [...] natomiast ktoś [...] niezrównoważony psychicznie, biorąc mnie za prezydenta, może mi jakąś krzywdę zrobić". Z chwilą objęcia funkcji premiera, w lipcu 2006 r. do 16 listopada 2007 r. korzystał on z przysługującej mu prawnie ochrony, która następnie została przedłużona na prośbę zainteresowanego. 27 marca 2009 r. prezes PiS został pozbawiony specjalnej ochrony BOR. BOR opuszcza Jarosława Kaczyńskiego, „Gazeta Wyborcza” z 28-29 marca 2009. Cała sprawa zasługiwałaby zapewne na szersze potraktowanie, mając na uwadze obu polityków-bliźniaków, ich interesy, ambicje, poczucie wartości, zabieganie o prestiż, wreszcie obsesje, a także wyczucie interesu publicznego, wreszcie przyzwoitość.

33 ,Świat polityki to środowisko - konstatują Robins i Post - które z nieodpartą siłą przyciąga jednostki i grupy o cechach paranoicznych [...] Paranoja jest przesadną formą wypróbowanego w polityce stylu czujnej podejrzliwości, uważnej obserwacji i wykorzystywania okazji. Jej siła w polityce bierze się również z tego, że paranoja po- 
W znacznej mierze przyczynia się on do budowania w świecie obrazu polityków polskich jako osobników swarliwych, wykazujących niedostatek instynktu państwowego, przedkładających prywatne ambicje, ale i fobie nad rację stanu ${ }^{34}$.

W opozycji do standardów demokratycznych, wzorcem ustrojowo-politycznym stały się rozwiązania z okresu międzywojennego o znamionach autorytarnych, kiedy idea „sanacji” - adresowana do „znużonego” obywatela - skrywała rzeczywiste intencje i efekty działania obozu piłsudczykowskiego $^{35}$. Nie jest przypadkiem, że prezydent kreuje się na człowieka skromnego pod względem potrzeb materialnych i ambicji cywilizacyjnych, sugerując że uboższa, nieuprzywilejowana materialnie ni kulturowo część społeczeństwa, posiada nader cenne przymioty - uczciwość i poczucie sprawiedliwości oraz zdolność zrozumienia głębi formułowanych przez niego zamierzeń ${ }^{36}$. Jego wizerunek zdaje się odzwierciedlać tęskno-

trafi stymulować zarówno zaciekłą agresję skierowaną przeciw urojonym obiektom, jak i energiczną i skuteczną reakcję na rzeczywiste niebezpieczeństwo [...] paranoja wypacza przyjęte i użyteczne reakcje na zagrożenia. Paranoja polityczna jest więc siła tak niszczycielska, ponieważ wnosi patologiczne składniki, jakimi są podejrzliwość i urojenia, a także dlatego, że nie tylko uruchamia, ale i deformuje zachowania służące naprawie stanu rzeczy oraz właściwe praktyki polityczne". R. S. Robins, J. M. Post, Paranoja polityczna. Psychopatologia nienawiści, Warszawa 1999, s. 31. W tym kontekście wypadnie uznać za curiosum wymykające się jednoznacznej kwalifikacji niekorzystanie przez b. premiera z usług bankowych, wywołujące zaskoczenie i kpiny. „Trzymam pieniądze na koncie mamy. Nie jest to dziwactwo, lecz efekt doświadczeń”. Przywołując zdarzenie z 1991 r., wspomina on o ofercie założenia konta, którą zinterpretował jako próbę uwikłania go w niejasne relacje, w ramach których utraciłby kontrolę nad swoimi działaniami: „Ale tamta sytuacja uzmysłowiła mi, jak łatwo z kogoś zrobić aferzystę. Od tamtej pory nigdy nie założyłem konta. Nie chce dopuścić do sytuacji, że ktoś bez mojej wiedzy wpłaci na mój rachunek jakieś pieniądze, a na drugi dzień przeczytam o tym w gazecie". J. Kaczyński: Nie mam konta, wywiad dla „Wprost”, nr 20 z 20 maja 2007.

${ }^{34}$ Zasługują na uwagę rozważania Kazimierza Łastawskiego zawarte w pracy: Polska racja stanu po wstapieniu do Unii Europejskiej, Warszawa 2009, zarówno jeśli idzie o ich wartość scjentystyczno-poznawczą, jak i aplikacyjną.

${ }^{35}$ Symbolicznym zwieńczeniem działań sanacji była Ustawa z dnia 07.04.1938 o ochronie imienia Józefa Piłsudskiego, Pierwszego Marszałka Polski, Dz. U. 1938, Nr 25 poz. 219.

${ }^{36}$ Kwestią pozostaje na ile ów targeting odzwierciedla rzeczywiste nastawienie Lecha Kaczyńskiego, w jakiej zaś mierze skrywa pogardę i wrogość wobec ludzi „kłopotliwych”, niezależnie od ich statusu. „Panie, spieprzaj Pan! Spieprzaj, dziadu!” - to reakcja kandydata na prezydenta Warszawy na natarczywość warszawiaka, który po spotkaniu wyborczym (4 listopada 2002 r.) pytał go o opinię nt. wędrówki (uciecz- 
ty „szarego” obywatela. Tego, dla którego Polska narodowa, patriotyczna i katolicka, tragicznie doświadczona, odróżnialna od nieufnie traktowanego otoczenia, niosącego zagrożenie dla własnej tożsamości narodowej i kulturowej, „sprawiedliwa” pod względem statusu i potrzeb cywilizacyjnych - to obszar najcenniejszych doświadczeń i doznań oraz punkt wyjścia dla oceny współczesności i budowania przyszłości ${ }^{37}$.

Lojalność i zaufanie nie mają znamion merytorycznych relacji, są wartościami niestabilnymi, podlegającymi wahaniom zależnym od stanu emocjonalnego oraz wpływu najbliższego, darzonego afektem otoczenia; współpracowników, „sprawdzonych” w „bojach” towarzyszy, także tych, którzy przysporzą korzyści medialnych, politycznych etc. Miary ocen i wartościowania ludzkich działań nie podlegają obiektywnym regułom, są wypadkową nastrojów emocjonalnych oraz wyobrażeń o swej pozycji i roli w życiu publicznym, traktowanym jako obszar zewnętrznych przeciwności i zagrożeń. Urzędujący prezydent nie zachowuje bezstronności. Wyrażając obiektywnie - poprzez sposób odnoszenia do przeszłości, stosunek do sceny politycznej, dążenie do jej kształtowania, głoszone priorytety, wyznawany system wartości ideowo-politycznych - interesy formacji, z której się wywodzi, nieodmiennie pozostaje w jej orbicie. Wie-

ki) ,,szczurów” z partii do partii. „Rzeczpospolita” z 5 listopada 2002. „Czcząc” siódmą rocznicę „nowatorskiej metody komunikacji polityka ze społeczeństwem” na warszawskiej Pradze wybito monetę „,dziad”, którą można było operować (zakup, wymiana; równowartość 7 PLN) w siedmiu punktach (sklepy, knajpy) Warszawy. Dziadowska waluta, „Gazeta Wyborcza, stołeczna” z 6 listopada 2009.

${ }^{37} \mathrm{Na}$ tęsknoty i oczekiwania Polaka odpowiada obraz „człowieka polityki”, mającego „na swoim koncie piękną kartę związaną z Solidarnością [...] Wzruszenie Kaczyńskiego było rzeczywiście szczere. Jego skromność i prawdziwość wzruszała $\mathrm{z}$ kolei zebranych. Szeptano między sobą, że równie dużą rzeczą w świecie polityki jest pozostanie sobą, wierność wartościom wyniesionym z domu, przyzwoitość czy stałość poglądów. To wszystko udało się Kaczyńskiemu" - relacjonowano uroczystość uhonorowania przez „Tygodnik Solidarność” prezydenta Warszawy tytułem Człowieka Roku 2004 za zorganizowanie uroczystości rocznicowych Powstania Warszawskiego. Tytuł dla czlowieka Solidarności, „Tygodnik Solidarność” nr 1 (845) 7 stycznia 2005. Nie od rzeczy będzie przywołanie przemyśleń A. Kasińskiej-Metryki, która poddając analizie casus Bolesława Bieruta, zwraca uwagę na fakt, iż wokół niego - i za jego przyzwoleniem - podejmowano działania z zakresu ,politycznego marketingu”. Tworząc image głowy państwa, ,ukazywano Bieruta jako polityka oddanego narodowi, państwu polskiemu, rozlicznym sprawom obywateli [...] eksponowano pracowitość wodza; w oknach jego gabinetu stale - w dzień i w nocy płonęło światło". A. Kasińska-Metryka, Prezydenci Polskiej Rzeczypospolitej Polskiej 1989-1999, Kielce 2000, s. 37. 
lorakie sygnały sugerują: urzędujący prezydent z trudnością mieści się w formule ,prezydent wszystkich Polaków”. Wydaje się, iż o to zresztą nie zabiega.

Jawi się tu - wobec nierzadko niezrozumiałych i niewytłumaczalnych działań łamiących reguły „dojrzałego” uprawiania polityki - możliwość posłużenia się konceptem interpretacyjnym Floriana Znanieckiego. Otóż spośród osobników, którzy traktują władzę jako dobro autonomiczne, przysparzające im osobliwej przyjemności - niezależnie od motywacji autotelicznej czy instrumentalnej - możliwe jest, jego zdaniem, wyodrębnienie grupy, dla której jest ona rodzajem gry - „zabawy”. „Człowiekiem zabawy nazywamy takiego, u którego w życiu dojrzałym panują dążności osobotwórcze; rozwinięte pod wpływem kręgów rówieśników [...] w ciagu dzieciństwa i młodości”38 - powiada on, konstatując: „Znaczna część życia społecznego dorosłych - mówiąc wyraźniej, życie towarzyskie, polityka i wojna - jest w najgłębszej swej istocie zabawą dziecięcą zachowującą wszystkie cechy zasadnicze zabawy"39.

\section{Polityka zagraniczna w rydwanie ideologii i fobii}

Interesujące wnioski nt. koherentności Polski z Europą wynikają z analizy przeobrażeń polityki zagranicznej od $1989 \mathrm{r}^{40}$ Istotę polityki nakierowanej na przyszłość oddawała deklaracja nowo desygnowanego premiera. 12 września 1989 r. wygłaszając expose, zakreślił on podstawowe kierunki polityki zagranicznej, sygnalizując zamiar „wyzwolenia” się z ograniczeń narzuconych podziałem Europy i świata, ale też i obawy, by ich spełnienie nie skomplikowało sytuacji Polski. Zapowiedział ,pożegnanie się bez żalu" z blokami wojskowymi w momencie, kiedy bezpieczeństwo europejskie nie będzie wymagało ich istnienia. W tym kontekście za ważną wypadnie uznać deklarację, że cele „nadrzędne” polskiej polityki zagranicznej ,zachowują swoje znaczenie w każdych okolicznościach, bez względu na to, jaka orientacja polityczna obejmuje ster rządów”. Kon-

${ }^{38}$ F. Znaniecki, Ludzie teraźniejsi a cywilizacja przyszłości, Warszawa 1974, s. 259 .

39 Ibidem, s. 270.

40 Szerzej K. B. Janowski, Polska polityka zagraniczna w 1989... Dziesięć lat później, w: Polska w systemie międzynarodowym w dobie integracji europejskiej, red. M. Marczewska-Rytko, Lublin 2001. 
kretyzacją owej deklaracji było zdecydowane - w opozycji do niedawno obowiązującej orientacji - zakreślenie ram polityki w stosunku do Związku Radzieckiego, których „rozumne” potraktowanie „prowadzić musi do szukania rozwiązań uwzględniających z jednej strony interesy wielkiego mocarstwa, z drugiej - respektowanie suwerenności naszego państwa oraz pełnej swobody kształtowania przez nie porządków wewnętrznych”. Przemianę w obopólnych stosunkach sygnalizowała zapowiedź „oczyszczenia" pola współpracy poprzez wejrzenie w przeszłość i uwolnienia ich $\mathrm{z}$ jej tragicznych nawarstwień ${ }^{41}$. Zakreślona perspektywa stosunków ze Wschodem nabierała wagi wobec ulegających zintensyfikowaniu więzi z Zachodem.

Miniony okres dostarcza bogatego materiału mogącego stanowić podstawę dla analizy polityki zagranicznej, jej przeobrażeń i obecnego kształtu. Faktem jest, że znaczna część dylematów, przed jakimi stanęła Polska w 1989 r. nie straciły na aktualności. Polityka otwarcia na Zachód, przy ostrożnym i stopniowym odrzucaniu zależności od Wschodu, mieściła się w koncepcji zrównoważenia. W następnym okresie wyraźną przewagę zyskiwał priorytet zachodni, przynosząc wszakże zaniedbanie kierunku wschodniego. Zgoda na zbliżenie Polski do Zachodu poprzez między innymi wchodzenie $w$ jego zorganizowane struktury - NATO i UE - w rzeczywistości połączyła większość ugrupowań na polskiej scenie politycznej. Wskutek jednak dominacji formacji „,solidarnościowej”, w której z czasem narastało ciążenie ku przeszłości, afektywność i ksenofobia, doszło nie tylko do podważenia idei „równowagi”, lecz do zaniku wysiłku na rzecz sformułowania nowej koncepcji stosunków ze Wschodem. Mieniące się ,prawicą"- przypisujące sobie prawo do dysponowania etosem ,S" - ugrupowania polityczne, wywierające decydujący wpływ w polityce wewnętrznej i zagranicznej, ulegały syndromowi ,,antykomunistycznemu". Dystans wobec Wschodu, przeradzał się w nieufność, przybierając momentami formę wrogości.

Polska scena polityczna pozostaje pod przemożnym wpływem afektywnego pojmowania i przeżywania przeszłości. Ugrupowania „solidarnościowe” (post-) traktują ją jako klucz do definiowania współczesności

41 Nowa sytuacja - nowe myślenie. Wspólny komunikat, ,Rzeczpospolita” z 28 listopada 1989. 26 listopada Mazowiecki złożył kwiaty pod krzyżem w Katyniu, znajdującym się w miejscu, w którym miał stanąc pomnik pomordowanych oficerów polskich, a także pod obeliskiem upamiętniającym śmierć żołnierzy radzieckich. Niech żyje polski rzqd, „Gazeta Wyborcza” z 28 listopada 1989. 
i przyszłości. W istocie dążą do zakonserwowania układu bipolarnego, w ramach którego antagonizm między „,komunizmem” a siłami cywilizacji zachodniej ma być głównym elementem stosunków międzynarodowych. W rezultacie segment wschodni polskiej polityki zagranicznej w znacznym stopniu określają postawy i zachowania defensywne; przeważa traktowanie Rosji jako synonimu wrażego komunistycznego imperium $^{42}$. Niezdolność odrzucenia balastu przeszłości, ideologizacja relacji z Rosją, sprawia, że na tym kierunku przeważa chaos, żywiołowość i brak pozytywnych działań. Polska nie kryje ambicji, by jej wizja polityki wschodniej stała się udziałem Europy. Ta zaś zachowuje powściągliwość ${ }^{43}$.

Aktualne pozostaje znalezienie się (ugruntowanie) w strefie bezpieczeństwa gwarantowanego integracją z Zachodem, ale równocześnie racjonalne i pragmatyczne ułożenie poprawnych (niekonfliktowych) stosunków ze Wschodem (Rosją, Ukrainą, Białorusią, krajami nadbałtyckimi). Kwestia zawiera się w zdolności państwa do realizacji interesów narodowych w konkretnych warunkach geopolitycznych - konkurencji,

42 Państwa otaczające Rosję to elementy ofensywnego kordonu „sanitarnego" (z tarczą antyrakietowa). Poparcie „pomarańczowej” rewolucji na Ukrainie, wspieranie ,antyrosyjskiej” Gruzji, misja ,zaszczepiania” wolności i demokracji na Białorusi nie mają na względzie pragmatycznie pojmowanych interesów Polski. Są odbiciem niewyrafinowanej strategii, ufundowanej na misji „cywilizacyjnej”, martyrologii, fobiach i frustracji, afektywności i konfliktowości... skazanej na fiasko. W przypadku Białorusi, to instrumentalizowanie mniejszości polskiej, eskalacja konfliktu, ingerencja w sprawy suwerennego państwa oraz posługiwanie się ,czarnym” PR i demagogią. Próby wyjścia z impasu odbija artykuł opublikowany 19 lutego 2010 r. w „Gazecie Wyborczej”, która nb. ma wyjątkowe ,zasługi” we wzmaganiu konfliktu i jego dramatyzowaniu (tytuł artykułu: Co powiemy Łukaszence). Por. rzeczowa rekapitulacja polityki wobec Białorusi, w: B. Dunat, Piata kolumna. Polacy na Białorusi, „NIE” nr 8 z 18.02.2010.

43 „Dziwna jest ta «polityka wschodnia». Wydawałoby się, że powinna być przede wszystkim sztuką użytkową. A tu wielkie puste słowa, sentymenty, duch romantyzmu i całkowity brak pomyślunku praktycznego, pozytywistycznego. Wybałuszamy oczy na polityków zachodnich, którzy nie oglądając się na nas, poklepują przyjaźnie Putina po ramieniu i robią z Rosją kokosowe naftowe i inne interesy. Jak to - a my? Przecież Rosję znamy lepiej, jesteśmy mostem między nią i Zachodem - macie chodzić przez nasz most! A że most dziurawy - załatajcie sobie. Nic o nas i o Rosji bez nas! Bóg jest z nami! Rosja kala nasze wartości! To barbarzyńcy, dzieciobójcy. Gdzie wasza europejska solidarność? - W rurze przez Bałtyk?” - powiada nie bez gorzkiego i uzasadnionego sarkazmu Andrzej de Lazari, Polskie i rosyjskie problemy z rosyjskościa, Łódź 2009, s. 193. 
uzyskiwania przewagi, bądź zawierania sojuszy czy kompromisów, dokonywania wyborów, których sens sprowadza się do realnego pojmowania racji stanu, ufundowanej na racjonalizacji potrzeb Polaków.

Czy daleko czy blisko kulturowo Polakom do Europy? Doprawdy trudno udzielić odpowiedzi jednoznacznej. Ich wizerunek zdominowały jednak osoby, które zajmują ważne miejsce na polskiej scenie politycznej. Ich zaś postawy i zachowania mogą wywoływać konsternację. Nierzadko godzą one w racjonalną strategię absorpcji „europejskości”. Przyczyniają się do kształtowania wśród Europejczyków obrazu Polski - kraju politycznie nieprzewidywalnego, skłóconego, w którym prawo, konstytucja nie wyznaczają twardych standardów działania państwa (i jego funkcjonariuszy), dryfującego ku konfesyjności, poddającego się i urzeczywistniającego określoną ideologię. Kraju, w którym dyskurs polityczny zdominowany jest przez konflikt, powodowany przebrzmiałymi symbolami, a walka polityczna pojmowana jest w perspektywie zupełnego unicestwienia przeciwników. Skoncentrowanego na sobie, swej tożsamości, ksenofobicznego wobec sąsiednich nacji, przedkładającego przeszłe spory, waśnie i krzywdy nad interes ufundowany na racjonalnym pojmowaniu racji stanu. Kraju wrażliwego na punkcie swej tożsamości, domagającego się szacunku, objawiającego misyjną dążność do jej zaszczepienia u innych... w sercu Europy.

Warszawa, luty 2010

\section{Summary}

The paper touches upon the issue of the cultural challenges which Poland and the Poles have faced since 1989, in the context of Poland's integration with Western Europe, which commenced then. The starting point of the analysis is the typology of political cultures of Almond, Verba and Powell. The paper mainly focuses on the manner in which politics is exercised and on Poland's foreign policy. In the conclusion it attempts to answer the question of whether Poles are culturally close to, or far away from Europe. The complexity of the issue, however, leads to the conclusion that despite the numerous examples the paper refers to, it is exceptionally difficult to answer this question unequivocally. 
